\title{
KEHATI-HATIAN NOTARIS DALAM MENJALANKAN JABATANNYA TERKAIT PEMBERIAN SALINAN/GROSSE/KUTIPAN AKTA
}

\author{
Lewis Andreas Ifran
}

\author{
Universitas Gadjah Mada, Indonesia, lewis.a.i@mail.ugm.ac.id
}

\begin{abstract}
Notary is a position that was born because of the needs of the community. In development in a written regulation or unwritten policy from people who want the intervention of a notary as an absolute requirement, the choice of the authority of a notary, an official other than a notary. Obligation to keep confidential belief which is the will conveyed by the presenter $(-s)$ is born automatically because of the position of a notary. Notary have an obligation to make Original of the Deed and keep them as a protocol, a notary to people who have a direct interest in the Original of the Deed, heirs, or the person obtaining the right is given Original Copy of a Deed, grosse, or excerpt of a deed. Notary who faced with the difficulty of determining whether one can obtain Original Copy of a Deed/grosselexcerpt deed in order to ask the person concerned to ask for a written power of attorney or a court order to issue and provide Original Copy of a Deed/grossel excerpt of a deed to the party requesting the notary. Sanctions given for not maintaining confidentiality by a notary is criminal, civil, imprisonment and fines, administration, and code of ethics. So to avoid sanctions, it is better for a notary to make a written power of attorney from a person who has a direct interest in the original of the deed/heir/person who has the right to submit original copy of a deed/grosselexcerpt of a deed.
\end{abstract}

Keywords: notary responsibility, secret of orginal of the deed, trust

\begin{abstract}
Abstrak
Notaris merupakan jabatan yang lahir karena kebutuhan masyarakat. Dalam perkembangannya dalam suatu peraturan tertulis maupun kebijakkan yang bersifat tidak tertulis dari masyarakat yang mengkehendaki adanya campur tangan dari notaris sebagai syarat mutlak, pilihan kewenangan notaris, pejabat selain notaris. Kewajiban untuk merahasiakan terhadap kepercayaan yang merupakan kehendak yang disampaikan oleh penghadap (-para) lahir sendirinya karena jabatan notaris. Notaris memiliki kewajiban untuk membuat minuta dan menyimpannya sebagai protokol maka notaris kepada orang yang berkepentingan langsung pada akta, ahli waris, atau orang yang memperoleh hak diberikan salinan/grosse/kutipan akta. Notaris yang dihadapkan pada sulitnya menenentukan apakah seseorang bisa mendapatkan salinan/grosse/kutipan akta agar dapat meminta yang bersangkutan untuk meminta kuasa tertulis atau penetapan pengadilan untuk mengeluarkan dan memberikan salinan/grosse/kutipan pada pihak yang meminta kepada notaris. Sanksi yang diberikan terhadap tidak menjaga kerahasiaan oleh notaris adalah pidana, perdata, pidana penjara dan denda, administrasi, dan kode etik. Sehingga untuk menghindari sanksi-sanksi ada baiknya notaris menyuruh membuat kuasa tertulis dari orang yang berkepentingan langsung pada akta/ahli waris/orang yang memperoleh hak untuk menyampaikan salinan/grosse/kutipan akta.
\end{abstract}

Kata Kunci: Kewajiban Notaris, Rahasia dalam akta, Kepercayaan 


\section{Pendahuluan}

Notaris merupakan jabatan yang lahir karena kebutuhan masyarakat akan suatu surat yang memiliki kekuatan pembuktian sempurna di hadapan pengadilan. ${ }^{1}$ Sejarah notariat di Indonesia tidak bisa lepas dari sejarah notariat Belanda dan Perancis. Indonesia merupakan jajahan dari Belanda, sehingga diterapkan di Indonesia menggunakan asas concordantie. ${ }^{2}$ Dalam perkembangan jaman, Peraturan Jabatan Notaris (selanjutnya PJN) semakin usang dan diharapkan terdapat pergantian. PJN telah berlaku selama hampir 103 tahun dengan perubahan sampai dengan dikeluarkannya Undang-undang Republik Indonesia nomor 30 tahun 2004 tentang Jabatan Notaris sebagaimana telah diubah

\footnotetext{
1 Akta yang dibuat oleh atau dihadapan notaris memiliki 3 kekuatan yaitu kekuatan pembuktian lahiriah (Uitwendige Bewijskracht), kekuatan pembuktian formal (Formele Bewijskracht), dan Kekuatan Pembuktian Material (Materiele Bewijskracht), lihat dalam GHS Lumban Tobing, Peraturan Jabatan Notaris, Erlangga, Jakarta, 1999, hlm. 55-62,

${ }^{2}$ Raden Soegondo Notodisuryo, Hukum Notariat di Indonesia suatu penjelasan, RajaGrafindo Persada, Jakarta, 1993, hlm. 22,
}

dengan Undang-undang Republik Indonesia Nomor 2 tahun 2014 tentang perubahan atas Undang-undang Republik Indonesia nomor 30 tahun 2004 tentang Jabatan Notaris (selanjutnya UUJN). Materi yang termuat dalam UUJN yang ternyata beberapa materinya tidak berbeda dengan PJN. Kewenangan Notaris terutama berdasarkan Pasal 15 ayat (1) UUJN, yaitu:

"Notaris berwenang membuat Akta autentik mengenai semua perbuatan, perjanjian, dan penetapan yang diharuskan oleh peraturan perundangundangan dan/atau yang dikehendaki oleh yang berkepentingan untuk dinyatakan dalam Akta autentik, menjamin kepastian tanggal pembuatan Akta, menyimpan Akta, memberikan grosse, salinan dan kutipan Akta, semuanya itu sepanjang pembuatan Akta itu tidak juga ditugaskan atau dikecualikan kepada pejabat lain atau orang lain yang ditetapkan oleh undang- undang"

Sedangkan kewenangan antara lain diatur dalam Pasal 15 ayat (2) dan (3) UUJN yaitu: “(2)Selain kewenangan sebagaimana dimaksud pada ayat (1), Notaris berwenang pula

a. mengesahkan tanda tangan dan menetapkan kepastian tanggal surat di bawah tangan dengan mendaftar dalam buku khusus; 
b. membukukan surat di bawah tangan dengan mendaftar dalam buku khusus;

c. membuat kopi dari asli surat di bawah tangan berupa salinan yang memuat uraian sebagaimana ditulis dan digambarkan dalam surat yang bersangkutan;

d. melakukan pengesahan kecocokan fotokopi dengan surat aslinya;

e. memberikan penyuluhan hukum sehubungan dengan pembuatan Akta;

f. membuat Akta yang berkaitan dengan pertanahan; atau

g. membuat Akta risalah lelang.

(3) Selain kewenangan sebagaimana dimaksud pada ayat (1) dan ayat (2), Notaris mempunyai kewenangan lain yang diatur dalam peraturan perundangundangan."

Akta notaris memiliki kekuatan

pembuktian sempurna adalah akibat dari ketentuan perundang-undangan yang merupakan keharusan adanya akta autentik sebagai alat pembuktian, tugas, sekaligus kepercayaan yang dibebankan kepada Notaris. $^{3} \quad$ Masyarakat memberikan kepercayaan terhadap notaris dalam menkonstantir kehendak para pihak atau notaris memberikan kejadian yang

\footnotetext{
${ }^{3}$ GHS Lumban Tobing, Op. cit. hlm. 54,
}

disaksikan notaris dalam menjalankan jabatan. $^{4}$ Hubungan penghadap (-para) dengan notaris adalah hubungan yang khas atas kepercayaan untuk membantu menemukan apa yang dikehendaki oleh penghadap (-para), bukan suatu kuasa, pengurusan bukan juga suatu perjanjian. Terhadap keraguan-raguan notaris jika kehendak penghadap (-para) akan bertentangan dengan ketertiban, kesusilaan umum, undang-undang maka notaris dapat menolak untuk memberikan bantuan. Menghadap kepada notaris adalah kehendak bebas setiap orang, namun dalam tindakan tertentu peran notaris adalah mutlak. Tanpa adanya campur tangan dari seorang notaris, maka syarat terhadap perbuatan yang dikehendaki tidak akan lahir atau dikabulkan. Dalam perkembangannya

\footnotetext{
${ }^{4}$ Dalam Pasal 1868 Kitab Undang-undang Hukum Perdata merupakan lahirnya jabatan notaris, "suatu akta autentik yalah suatu akta yang, didalam bentuk yang ditentukan oleh undang-undang, dibuat oleh atau di hadapan pegawai-pegawai umum yang berkuasa untuk itu di tempat dimana akte dibuatnya." akta yang dibuat dihadapan merupakan akta partij sedangkan akta yang dibuat oleh merupakan akta pejabat.
} 
terdapat syarat administratif yang ditetapkan dalam suatu peraturan maupun kebijakkan yang bersifat tidak tertulis dari masyarakat yang mengkehendaki adanya campur tangan dari notaris agar "kuat" kekuatan pembuktiannya. ${ }^{5}$ Masyarakat membuat akta karena kewajiban dari instasi setelah mendapatkan salinan dari minuta, memberikan kepada instasi bersangkutan yang meminta salinan akta autentik. Notaris dalam membuat akta wajib berbentuk minuta dan menyimpannya sebagai protokol

\footnotetext{
5 Masyakat membawa surat dibawah tangan untuk dilegalisasi atau di daftarkan di buku khusus notaris, dengan anggapan adanya cap jabatan notaris sudah dapat menyakinkan bahwa surat berasal dari notaris.

Kebijakkan tertulis misalnya pada Pasal 24 ayat (1) huruf d Peraturan Menteri Kesehatan Republik Indonsia Nomor 38 tahun 2016 Tentang Penyelenggaraan Transplantasi Organ yaitu "Menyerahkan pernyataan tertulis tidak membeli organ tubuh dari calon pendonor atau melakukan perjanjian khusus dengan calon pendonor, yang dituangkan dalam bentuk akte notaris atau pernyataan tertulis yang disahkan oleh notaris".

Kebijakkan tidak tertulis misalnya pengambilan jaminan kredit atau deposito atau tabungan milik almarhum pada bank yang memerlukan akta autentik yang dibuat dihadapan notaris walaupun sudah dibuat dalam surat dibawah tangan yang disahkan lurah dan camat. Walaupun ada ketentuan bagi golongan beberapa penduduk untuk membuat keterangan waris dibawah tangan, namun kenyataannya bank meminta keterangan waris dibuat dihadapan notaris, lihat Aden Ahmad, Sihabudin \& Siti Hamidah, "Kepastian Hukum Surat Keterangan Waris Sebagai Persyaratan Pengambilan Jaminan Kredit", Jurnal Selat, Vol. 6 No. 1, Oktober 2018, hlm 22,
}

sesuai dengan kewajibannya yang termuat dalam Pasal 16 ayat (1) huruf b UUJN. Kewajiban dalam ketentuan ini dimaksudkan untuk menjaga keautentikan suatu akta dengan menyimpan akta dalam bentuk aslinya, sehingga apabila ada pemalsuan atau penyalahgunaan grosse, salinan, atau kutipannya dapat segera diketahui dengan cara mencocokkan salinan akta, kutipan akta dan grosse akta dengan asli aktanya (minuta akta). ${ }^{6}$ Minuta akta yang telah disahkan notaris kemudian disimpan notaris sebagai protokol, kepada penghadap (-para) diberikan salinan atau kutipan sesuai dengan kebutuhan masingmasing. Dalam melakukan penyampaiannya masyarakat notaris perlu cermat. Masyarakat banyak mempercayakan kepada notaris akan penyampaiannya, namun beberapa peraturan tertulis hanya melalui perantara kepada notaris, alternatife kepada notaris dan hanya

\footnotetext{
6 Ivo Dewi Kumalawati, M. Khoidin, dan Nurul Ghufron, "Karakteristik Minuta Akta Notaris Sebagai Arsip Negara", Lex Humana Jurnal Hukum dan Humaniora, Vol. 1, No. 2, April-September 2017, hlm. 133,
} 
penghadap (-para) yang berkewajiban

menyampaikannya.

\section{Rumusan Masalah}

Bagaimana kehati-hatian notaris merahasiakan dan terhindar dari sanksisanksi dalam menjaga kerahasian isi akta?

\section{Tujuan Penelitian}

Untuk mengetahui dan menganalisis bagaimana seharusnya notaris berhati-hati terhadap kepercayaan yang diberikan masyarakat dan cara-cara yang dilakukan agar terhindar dari sanksi-sanksi terkait pemberian atau pernyampaian salinan/grosse/kutipan akta.

\section{Metode Penelitian}

Jenis penelitian yang digunakan adalah penelitian hukum normatif, ${ }^{7}$ yaitu penelitian yang dilakukan dengan cara mengkaji Peraturan Perundang-Undangan yang berlaku atau

${ }^{7}$ Disemadi, H. S., Yusro, M.A., Shaleh, A.I (2020) Perlindungan Hukum Keputusan Bisnis Direksi BUMN Melalui Business Judgement Rule Doctrine, Jurnal Jurisprudence, Vol.10., No. 01. Pp. 127-145. diterapkan terhadap suatu permasalahan tertentu. Jenis pendekatan yang digunakan dalam penelitian ini adalah pendekatan pendekatan konsep (conceptual approach) dan pendekatan perundangundangan (statute approach). Umumnya dalam penelitian hukum terdapat beberapa pendekatan yang lain selain pendekatan konsep (conceptual approach) dan pendekatan perundangundangan (statute approach), yakni pendekatan kasus (The Case Approach), pendekatan sejarah (Historical Approach) dan pendekatan komparatif (Comparative Approach) ${ }^{8}$ Bahan hukum yang digunakan dalam penelitian ini bersumber dari kepustakaan, yang terdiri dari:

1. Bahan Hukum Primer terdiri atas:

a. Undang-undang Republik Indonesia nomor 30 tahun 2004 tentang Jabatan Notaris,

b. Undang-undang Republik Indonesia Nomor 2 tahun 2014 tentang

\footnotetext{
${ }^{8}$ Peter Mahmud Marzuki, Penelitian Hukum, Preneda Media, Jakarta, 2005, hlm. 93,
} 
perubahan atas Undang-undang

Republik Indonesia nomor 30 tahun

2004 tentang Jabatan Notaris,

c. Kitab Undang-Undang hukum

Perdata.

2. Bahan Hukum Sekunder terdiri atas:
a. buku ilmu hukum
b. jurnal hukum
c. tesis

Untuk mendapatkan data yang diperlukan, pengumpulan data dilakukan melalui studi kepustakaan (library research), studi kepustakaan ini dilakukan untuk mendapatkan atau mencari konsepsikonsepsi, teori-teori, asas-asas dan hasilhasil pemikiran lainnya yang berkaitan dengan permasalahan penelitian ini.

Teknik analisis bahan hukum dalam penelitian ini adalah setelah semua bahan hukum terkumpul baik dari bahan hukum primer dan sekunder kemudian diklasifikasikan secara kualitatif sesuai dengan permasalahan. Bahan hukum tersebut dianalisa dengan teori - teori yang relevan kemudian disimpulkan untuk menjawab permasalahan dan akhirnya bahan hukum disajikan dalam deskritif analitis.

\section{Hasil Penelitian dan Pembahasan}

Kehadiran notaris sebagai pembuat akta autentik atau kewenangan lain dari UUJN memberikan kepercayaan notaris dalam masyarakat. Masyarakat yang meminta bantuan dari notaris untuk membuat akta dapat dibedakan menjadi 3, yaitu kesadaran hukum untuk memberikan kepastian hukum terutama dalam pembuktian perdata, membutuhkan notaris untuk memberikan solusi hukum dan hanya akta notaris suatu perbuatan dapat diterima. ${ }^{9}$ Kewenangan notaris dituangkan dalam beberapa peraturan tertulis mengkehendaki adanya campur tangan notaris sebagai syarat mutlak, pilihan kewenangan notaris, pejabat selain notaris.

\footnotetext{
9 Asri Muji Astuti, "Honorarium Notaris Sebagai Upaya Untuk Melindungi Hak Notaris Guna Kepastian dan Keadilan", Jurnal Hukum UB, tanpa volume, tanpa bulan, 2016, hlm. 8-10,
} 
a. Mutlak

Harusnya campur tangan notaris merupakan bagian dari perjanjian formil $^{10}$, tanpa adanya akta notaris mengakibatkan perbuatan hukum tidak sah, misalnya:

1. Pemberian jaminan fidusia, diatur dalam Pasal 5 ayat (1) Undangundang Nomor 42 tahun 1999 tentang Jaminan Fidusia, ${ }^{11}$

2. Pendirian dan perubahan anggaran dasar serta perubahan data Perseroan Terbatas (selanjutnya

10 Perjanjian formil adalah perjanjian yang selain adanya kata sepakat juga dibutuhkan formalitas tertentu bagi pembentukan beberapa jenis perbuatan hukum, tanpa adanya akta autentik notaris akan berikan batal demi hukum atau non-existent dalam artian yuridis dogmatis, lihat dalam Herlien Budiono, Demikian Akta Ini Tanya Jawab Mengenai Pembuatan Akta Notaris Di Dalam Praktik, Citra Aditya Bakti, Bandung, 2018, hlm 43-44,

${ }^{11}$ Terkait dengan kuasa pemasangan fidusia, Ikatan Notaris Indonesia lewat B bagian eksternal, nomor 1 sub akta Fidusia, Rapat Pleno Pengurus Pusat Yang DIperluas pada tanggal 12 Januari 2017 di Balikpapan menyarankan bahwa Kuasa yang digunakan untuk pemberian jaminan Fidusia haruslah kuasa otentik yang dibuat di hadapan Notaris. Kesatuan sikap Ikatan Notaris Indonesia bukan lah pengikat bagi pihak ketiga, hanya sebagai pengikat bagi anggota Ikatan Notaris Indonesia. Konsekuensi bagi anggota Ikatan Notaris Indonesia yang tidak mengikuti hanya dapat disanksi kode etik yang bersifat keanggotaan di perkumpulan bersangkutan, tidak berakibat pada akta maupun jabatan Notaris,
PT), diatur berturut-turut dalam

Pasal 7 ayat (1), Pasal 23 ayat (4)

dan (5) Undang-undang Nomor 40

tahun 2007 tentang Perseroan

Terbatas sebagaimana telah diubah

dengan Undang-undang Nomor 11

tahun 2020 tentang Cipta Kerja,

3. Pendirian dan perubahan

perkumpulan berbadan hukum,

diatur dalam Pasal 1653

KUHPerdata buku III, dan

kemudian diatur lebih lanjut dalam

Staatsblad 1870-64 tentang

Kedudukan Badan Hukum dari

Perkumpulan

(Rechtspersoonlijkheid van

Vereenigingen) dan Staatsblad

1942-13 jo 14 tentang

Perkumpulan Indonesia

(Inlandsche Vereniging), Pasal 12

ayat (4) huruf a dan Pasal 17 ayat

(3) dan Pasal 18 Peraturan Menteri

Hukum dan Hak Asasi Manusia 
Republik Indonesia Nomor 3

Tahun 2016 tentang Tata Cara

Pengajuan Permohonan

Pengesahan Badan Hukum dan

Persetujuan Perubahan Anggaran

Dasar Perkumpulan (selanjutnya

Permenkumham 3/2016). ${ }^{12}$

4. Pendirian dan perubahan anggaran

dasar Persekutuan Komanditer

(Commanditaire Vennotschaap),

Persekutuan Firma, dan

Persekutuan Perdata, yang diatur

berturut-turut dalam Pasal 22 Kitab

Undang-undang Hukum Dagang

juncto Pasal 12 ayat (4) huruf a dan

Pasal 18 ayat (3) huruf a Peraturan

${ }^{12}$ Perkumpulan juga diatur dalam undang-undang nomor 17 Tahun 2013 tentang Organisasi Kemasyarakatan, namun seharusnya pengaturan mengenai perkumpulan seharusnya terpisah karena memiliki karakteristik yang berbeda. Bagi perkumpulan tidak berbadan hukum akibatnya diatur dalam Pasal 17 Tahun 2013 tentang Organisasi Kemasyarakatan. Lihat Kristina Viri, Cornellius Bramantya, Josua Navirio Pardede, "Urgensi Rancangan Undang-Undang Perkumpulan”, Jurnal Legislasi Indonesia, Vol. 18 No. 3, September 2021, hlm. 334, dan Kementerian Hukum Dan Hak Asasi Manusia RI Badan Pembinaan Hukum Nasional 2016, Naskah Akademik Rancangan Undang-Undang Tentang Perkumpulan, tanpa penerbit, tanpa tempat terbit, 2016, hlm. 112
Menteri Hukum dan Hak Asasi

Manusia Republik Indonesia

Nomor 17 Tahun 2018 tentang

Pendaftaran Persekutuan

Komanditer, Persekutuan Firma,

dan Persekutuan Perdata

(selanjunya Permenkumham

17/2021),

5. Pembuatan, perubahan dan

pencabutan (pembatalan) akta

perjanjian kawin, diatur dalam

Pasal 29 Undang-undang Nomor 1

tahun 1974 tentang Perkawinan

junctis Putusan Mahkamah

Konstitusi 69/PUU-XIII/2015,

Surat Direktorat Jenderal

Kependudukan dan Pencatatan

Sipil Kementrian Dalam Negeri

Republik Indonesia nomor

472.2/5876/Dukcapil (selanjutnya

SE Dukcapil), Surat Direktorat

Jenderal Bimbingan Masyakarat

Islam Kementrian Agama Republik 
Indonesia nomor

B.2674/DJ.III/KW.00/9/2017

(selanjutnya SE Kementrian Agama),

b. Pilihan kewenangan

Pernyataan tertulis tidak membeli, yang dituangkan dalam bentuk akte notaris atau pernyataan tertulis yang disahkan oleh notaris, yang diatur dalam Pasal 24 ayat (1) huruf d Peraturan Menteri Kesehatan Republik Indonesia Nomor 38 Tahun 2016 Tentang Penyelenggaraan Transplantasi Organ,

c. Jabatan selain notaris yang membuat

Pejabat lain yang ditunjuk untuk membuat akta lain

1. Surat kuasa membebankan hak tanggungan (selanjutnya SKMHT), diatur dalam Pasal 15 ayat (1) Undang-undang nomor 40 tahun 1996 tentang Hak Tanggungan atas Tanah Beserta Benda-Benda yang
Berkaitan dengan Tanah (selanjutnya UUHT),

2. Pemberian wakaf, diatur dalam Pasal 37 Peraturan Pemerintah Republik Indonesia Nomor 42 Tahun 2006 tentang Pelaksanaan Undang-Undang Nomor 41 Tahun 2004 ,

3. Tanda bukti sebagai ahli waris, diatur dalam Pasal 111 ayat (1) huruf c, Peraturan Menteri Negara Agraria/ Kepala Badan Pertanahan Nasional Nomor 16 Tahun 2021 tentang Perubahan Ketiga atas Peraturan Menteri Negara Agraria/Kepala Badan Pertanahan Nasional Nomor 3 Tahun 1997 tentang Ketentuan Pelaksanaan Peraturan Pemerintah Nomor 24 Tahun 1997 tentang Pendaftaran Tanah (selanjunya Perkaban 16/2021), 
d. Pilihan terhadap ada atau tidak ada campur tangan dari Notaris

1. Permohonan Kredit baru, perpanjangan jangka waktu, tambahan Kredit atau Pembiayaan maupun permohonan perubahan persyaratan Kredit atau Pembiayaan atau Pembiayaan diajukan secara tertulis, diatur dalam Pasal 2 ayat (1) dan (2) juncto lampiran huruf E, huruf 1, Peraturan Otoritas Jasa Keuangan

Nomor 42 /Pojk.03/2017 tentang

Kewajiban Penyusunan dan

Pelaksanaan Kebijakan

Perkreditan atau Pembiayaan

Bank bagi Bank Umum,

2. Perjanjian Jual Beli (selanjutnya PJB), yang diatur dalam Pasal 1 angka 1, Pasal 22k Peraturan Pemerintah Republik Indonesia Nomor 12 Tahun 2021 tentang Perubahan atas Peraturan
Pemerintah Nomor 14 Tahun 2016 tentang Penyelenggaraan Perumahan dan Kawasan Permukiman (selanjutnya PP 12/2021) juncto, ${ }^{13}$

3. Penyerahan piutang atas nama (cessie), diatur dalam Pasal 613 ayat (1) KUHPerdata.

4. Hibah benda bergerak diatur dalam Pasal 1682 KUHPerdata, ${ }^{14}$

5. Pembuatan wasiat dikelompokkan yang diatur dalam KUHPerdata

\footnotetext{
${ }^{13}$ Terhadap ketentuan ini hanya diatur untuk pelaku pembangunan, lihat dalam Pasal 1 angka 11 PP 12/2021. Terhadap PJB yang dapat dicatatkan adalah yang dibuat dihadapan notaris, lihat Pasal 127B ayat (2) huruf a Perkaban 16/2021

${ }_{14}$ Kewajiban ini tidak berlaku berdasarkan Surat Edaran Mahkamah Agung 3 tahun 1963 tanggal 5 September yang dipandang sebagai anjuran kepada para hakim agar jangan ragu-ragu dan takut takut mengesampingkan ketentuan-ketentuan KUHPerdata, manakala mereka berpendapat bahwa ketentuan KUHPerdata sudah tidak sesuai lagi dengan rasa keadilan masyarakat, Lihat Badan Pembinaan Hukum Nasional Kementerian Hukum Dan HAM RI 2013, Naskah Akademik Rancangan Undang Undang Hukum Kontrak, tanpa penerbit, tanpa tempat terbit, 2013, hlm. 141

"Patut diperhatikan dengan seksama, sekalipun secara praktikal hingga saat ini pandangan SEMA 3 tahun 1963, relatif tidak menimbulkan persoalan dan dapat diterima, namun tetap berpotensi menimbulkan persoalan yang berkaitan dengan inharmonisasi antara undang - undang, karena sebagai konsekuensi logis terhadap pandangan ini Undang - undang (wetboek) yang berlaku saat ini ternyata justru meletakkan keabsahannya pada B.W. sebagai rechtboek." Lihat ibid, hlm. 142,
} 
dan yang diatur dalam Kompilasi

Hukum Islam (selanjutnya KHI)

a. Wasiat dalam KUHPerdata yaitu Wasiat terbuka/umum, diatur dalam Pasal 938-939

KUHPerdata, Wasiat Rahasia atau wasiat Tertutup, diatur dalam Pasal 940-942 KUHPerdata, Wasiat Olografis diatur dalam Pasal 935-936 KUHPerdata, Wasiat Darurat diatur dalam Pasal 946-948 KUHPerdata, Kesemua itu wajib campur tangan dari notaris, Walaupun pembuatan darurat wasiat tidak dihadapan notaris namun wasiat akan kehilangan kekuatannya jika tidak diserahkan kepada Notaris. Setelah adanya akta penyimpanan, berdasarkan Pasal $933 \quad$ KUHPerdata kekuatannya sama dengan surat wasiat umum (openbaar testament). ${ }^{15}$

b. KHI mengenal bentuk wasiat lisan dan wasiat tertulis berupa akta dibawah tangan dimana apabila wasiat lisan dan wasiat tertulis berupa akta dibawah tangan dibuat dengan disaksikan oleh minimal dua orang saksi, maka wasiat sudah dianggap sah. ${ }^{16}$

Notaris wajib menjalankan kewajibannya untuk merahasiakan isi aktanya termasuk merahasiakan semua pembicaraan-pembicaraan penghadap (para) bahkan pada waktu diadakannya persiapan-persiapan untuk membuat akta. ${ }^{17}$

15, lihat Anisah Aprilia, "Alternatif Bentuk Wasiat Bagi Tenaga Kesehatan dan Pasien Covid-19", Jurnal National Conference For Law Studies, Vol. 2, No. 1, tanpa bulan 2020, hlm 9,

${ }^{16}$ Lihat Pasal 195 ayat (1) KHI, lihat juga Paula Fransisca, Ro'fah Setyowati, "Wasiat Kepada Ahli Waris Menurut Kompilasi Hukum Islam dan Kitab Undang-Undang Hukum Perdata",Jjurnal Notarius, Vol. 11, No. 1, tanpa bulan 2018, hlm 117,

17 Siska Harun Buko, "Analisis Yuridis Tentang Kewajiban Notaris Dalam Memberikan Jasanya Kepada Masyarakat yang Tidak Mampu Berdasarkan UU No. 2 Tahun 2014", Jurnal Lex Privatum, Vol. V, No. 1, Jan-Feb 2017, hlm 91, 
Kewajiban untuk merahasiakan terhadap kepercayaan yang merupakan kehendak

yang disampaikan oleh penghadap (-para)

lahir sendirinya karena jabatan notaris. ${ }^{18}$

Kewajiban notaris untuk merahasiakan

kepercayaan kehendak dari penghadap (-

para) sudah wajib dijaga bahkan sebelum

notaris menjalankan jabatannya dengan

mengucap sumpah/janji sebagai termuat

dalam Pasal 4 ayat (2) UUJN, yaitu: "bahwa saya akan merahasiakan isi akta dan keterangan yang diperoleh dalam pelaksanaan jabatan saya." Pengucapkan sumpah/janji memiliki arti yang sangat mendalam bagi Tuhan, negara dan terutama masyarakat untuk mempercayakan rahasia yang telah disampaikan kepada notaris. ${ }^{19}$ Notaris akan dikenakan sanksi jika tidak menyampaikan kewajibannya untuk menyampaikan berita acara sumpah/janji jabatan Notaris kepada Menteri, Organisasi

${ }^{18}$ GHS Lumban Tobing, Op. cit., hlm. 118

19 Endang Purwaningsih, "Bentuk Pelanggaran Hukum Notaris Di Wilayah Provinsi Banten dan Penegakan Hukumnya", Jurnal Mimbar Hukum, Vol. 27, No. 1, Februari 2015, hlm. 23,
Notaris, dan Majelis Pengawas Daerah. ${ }^{20}$ Notaris yang tidak/belum mengucapkan sumpah/janji dan termasuk juga jika keputusan pengangkatan dibatalkan Menteri Hukum dan Hak Asasi Manusia karena lewat jangka waktu pengucapkan sumpah dilarang membuat akta karena tidak berwenang. ${ }^{21}$ Apabila notaris membuat akta, akta yang dibuatnya hanya dapat berlaku sebagai akta dibawah tangan jika terdapat tanda-tangan dari penghadap (-para) dalam beberapa perbuatan yang wajib dibuat akta autentik menjadikan akta batal demi hukum. $^{22}$

Kewajiban merahasiakan akta ditegaskan kembali dalam Pasal 16 ayat (1) UUJN huruf f, yaitu "merahasiakan segala

\footnotetext{
${ }^{20}$ Lihat Pasal 7 UUJN,

${ }^{21}$ Lihat Pasal 5 dan 6 UUJN,

${ }^{22}$ Lihat Pasal 1969 Kitab Undang-undang Hukum Perdata

Perlu diingat bahwa akta autentik memiliki asas praduga sah, sepanjang tidak dibuktikan sebaliknya oleh pengadilan, maka akta autentik tetap berlaku sebagai akta autentik dan tetap mengikat bagi penghadap (-para), lihat Innaka Dewi Hindra, Pieter Everhardus Latumeten, Widodo Suryandono, "Penerapan Asas Praduga Sah Terhadap Akta Notaris Dengan Adanya Figur Palsu (Studi Kasus Putusan Pengadilan Tinggi Banda Aceh Nomor 43/PDT/2017/PT.BNA)”, Jurnal Indonesia Notary, Vol. 1, No. 004, tanpa bulan 2019, hlm. 19,
} 
sesuatu mengenai akta yang dibuatnya dan segala keterangan yang diperoleh guna pembuatan akta sesuai dengan sumpah/janji jabatan, kecuali undang-undang menentukan lain." Akibat tidak dijalankan kewajiban dapat dikenakan sanksi peringatan tertulis, pemberhentian sementara, pemberhentian dengan hormat atau pemberhentian dengan tidak hormat. ${ }^{23}$ Sebagai kewajiban notaris untuk membuat minuta dan menyimpannya sebagai protokol maka notaris kepada orang yang berkepentingan langsung pada akta, ahli waris, atau orang yang memperoleh hak diberikan salinan, grosse, atau kutipan akta. ${ }^{24}$ Sanksi juga mengikuti apabila notaris tidak melanggarnya yaitu dapat dikenakan sanksi peringatan tertulis, pemberhentian sementara, pemberhentian dengan hormat

\footnotetext{
${ }^{23}$ Lihat Pasal 16 ayat 11 UUJN,

${ }^{24}$ Lihat Pasal 54 ayat (1) UUJN dan Lihat juga Ivo Dewi Kumalawati, M. Khoidin, dan Nurul Ghufron, Op. cit., hlm. 133, Notaris wajib menyimpan dan menjaga Minuta yang merupakan bagian dari Protokol yang dibatasi hanya dapat diberikan kepada Notaris, Notaris Pengganti, Notaris Pengganti Khusus, Pejabat Sementara Notaris, dan Majelis Pengawas Daerah Notaris,
}

atau pemberhentian dengan tidak hormat. ${ }^{25}$ Notaris tidak memberikan minuta merupakan konsekuensi logis karena minuta akta merupakan arsip negara yang merupakan kewajiban notaris disimpan sebagai protokol agar tidak hilang atau musnah/rusak. ${ }^{26}$ Notaris wajib menyimpan minuta dengan baik, aman, sangat hati-hati, dan melakukan tindakan untuk mengamankan minuta jangan sampai rusak, termasuk untuk tindakan pengaman tidak membawa keluar minuta dari dalam kantor. $^{27}$

UUJN tidak dijelaskan siapa yang dimaksud berkepentingan langsung pada akta. Pada pengertian sempit orang yang berkepentingan langsung pada akta adalah penghadap (-para) yang menyuruh notaris

\footnotetext{
${ }^{25}$ Lihat Pasal 54 ayat (2) UUJN,

${ }^{26}$ Minuta merupakan arsip vital karena perbuatannya tidak dapat diulang kembali pada hari, jam, tanggal, bulan dan tahun yang sama. Akta yang hilang tidak akan bisa dibuat kembali meskipun membuat akta yang sama dengan isi yang sama namun akan terbentuk pada keadaan peresmian akta. Jika notaris memalsukan mengenai kepastian hari, tanggal, bulan, tahun dan pukul menghadap yang tercantum dalam akta maka perbuatan Notaris dapat dikategorikan sebagai perbuatan pidana dengan tindak pidana Pasal 263, 264, 266 Juncto 55 atau 56 KUHP,

${ }^{27}$ Raden Soegondo Notodisuryo, Op. cit., hlm. 193,
} 
untuk membuat akta itu. Pada pengertian luas adalah mereka yang menjadi pihak pada isi akta, sekalipun tidak ikut menghadap pada notaris. Jadi bukan pihak dalam akta, akan tetapi pada akta dalam pengertian Pasal 1870 KUHPerdata. ${ }^{28}$ Penjelasan atas pihak yang berkepentingan selalu dikembalikan kepada pengertian "partij", yakni mereka yang meminta bantuan notaris untuk membuat akta notaris yang secara sukarela datang, agar akta itu menjadi bukti kehadirannya, keterangan yang diberikan atau perbuatan yang dilakukannya. ${ }^{29}$ Pemberian salinan kepada penghadap (-para) kepada notaris perlu mendapat perhatian, karena menjadi penghadap (-para) bisa juga untuk mewakili kepentingan seseorang atau badan hukum. Pemberian salinan/grosse/kutipan akta kepada penghadap (-para) yang hanya sebagai kuasa dan mewakili badan hukum perlu dipertimbangkan pada saat permintaan

${ }^{28}$ GHS Lumban Tobing, Op.cit., hlm. 265,

${ }^{29}$ GHS Lumban Tobing, Op.cit., hlm, 268, salinan/grosse/kutipan akta apakah kuasa yang diberikan masih berlaku atau diberikan kuasa untuk itu ${ }^{30}$ atau masih sah bertindak mewakili kepentingan seseorang atau badan hukum $^{31}$.

Ahli waris masuk sebagai titel umum dalam sebagai orang yang memperoleh hak yang dapat diberikan salinan/grosse/kutipan akta. ${ }^{32}$ Dalam hal ini ahli waris juga harus diberikan pembatasan misalnya ahli waris yang mendapatkan bagian waris karena harta percampuran dari harta bersama atau berdasarkan wasiat atau karena pergantian ahli waris. Penerima hak dengan titel khusus seperti para pembeli, legataris dan

\footnotetext{
${ }^{30}$ Pada umumnya kuasa dapat berakhir sebagaimana diatur dalam Pasal 1813 KUHPerdata juga diatur misalnya: selesainya tugas atau perbuatan hukum untuk mana kuasa diberikan, perbuatan hukum untuk mana kuasa diberikan tidak dapat dilaksanakan, jangka waktu pemberian kuasa telah berakhir, pengangkatan kuasa baru untuk menjalankan urusan yang sama, lihat Herlien Budiono, Op. cit., hlm. 126, 31 Suatu organ yang bisa bertindak untuk badan hukum masih dalam jangka waktu menjabat atau tidak diberhentikan dari jabatannya atau mengurusi perbuatan dalam pailit atau tidak dicabut berdasarkan penetapan hakim terkhusus perwalian orang tua yang masih hidup atau yang ditunjuk pengadilan, kekuasaan orang tua atau anak yang sudah tidak masuk perwalian dan kekuasaan orang tua ${ }^{32}$ GHS Lumban Tobing, Op.cit., hlm. 273,
} 
sebagainya. ${ }^{33}$ Penerima hak dengan tittle khusus adalah mereka yang dijadikan sebagai para penerima hak. Terhadap pemberi hak ada beberapa hal yang perlu diberikan penjelasan lebih kepada notaris misalnya pembeli yang membeli melalui perantara kuasa atau legataris yang belum ditetapkan ahli warisnya termasuk juga pengalihan hutang dengan cessie.

Pemberian salinan kepada penghadap (-para) yang datang untuk kepentingan sendiri tidak menjadi persoalan, namun yang perlu dipertimbangkan jika perantara melalui kuasa atau melalui jabatan atau kedudukan. Apabila yang mewakili orang atau badan hukum kehilangan kedudukannya dan meminta salinan/grosse/kutipan akta, maka notaris harus menolak permintaannya. ${ }^{34}$ Terhadap ahli waris atau orang yang berkepentingan yang telah ditetapkan berdasarkan suatu akta autentik atau surat dibawah tangan yang

\footnotetext{
${ }^{33}$ Ibid., hlm. 274,
}

${ }^{34}$ Ibid., hlm. 272, telah dibatalkan oleh suatu putusan pengadilan yang berkekuatan hukum tetap, notaris berhak untuk menolak. Sebelum dikeluarkan putusan pengadilan yang membatalkan suatu alat bukti tertulis notaris tidak memiliki kewenangan untuk menilai sah atau tidaknya suatu alat bukti tertulis karena kompetisi itu hanya terdapat pada hakim lewat putusan yang bersifat tetap. Sekalipun notaris ragu atau mengetahui yang bersangkutan bukan sebagai ahli waris atau pembeli yang sah tetap wajib memberikan salinan/grosse/kutipan akta jika diminta bahkan terhadap akta yang telah dibatalkan pengadilan dengan kekuatan hukum tetap.

Notaris yang dihadapkan pada sulitnya menenentukan apakah seseorang bisa mendapatkan salinan/grosse/kutipan akta agar dapat meminta yang bersangkutan untuk meminta kuasa tertulis untuk mengeluarkan dan mengambil atas nama orang yang berkepentingan langsung pada 
akta/ahli waris/orang yang memperoleh hak.

Permintaan sebuah salinan/grosse/kutipan akta juga dapat ditempuh dengan meminta penetapan pengadilan agar memerintahkan kepada notaris untuk mengeluarkan dan memberikan salinan/grosse/kutipan akta pada pihak yang meminta kepada notaris. ${ }^{35}$ Pengeluaraan salinan akta juga dapat dilakukan dalam suatu perkara yang membutuhkan salinan akta untuk suatu pembuktian dengan meminta mengeluarkan salinan akta secara darurat (dwanguit gifte van acten) yang dapat ditemukan dalam Pasal 848 Kitab Undang-undang Hukum Acara Perdata. ${ }^{36}$ Pertimbangan mengabulkan dan menolak biarlah hakim yang menentukan apakah seseorang layak untuk diberitahu rahasia yang dipercayakan kepada notaris. Notaris akan mengeluarkan salinan/grosse/kutipan atas dasar kuasa tertulis atau penetapan pengadilan yang memiliki kekuatan hukum tetap.

\footnotetext{
${ }^{35}$ Raden Soegondo Notodisuryo, Op. cit. hlm. 195,

${ }^{36}$ GHS Lumban Tobing, Op.cit., hlm. 195-196,
}

Notaris atau notaris pemegang protokol tidak diberikan batasan mengenai pengeluaran salinan/grosse/kutipan akta, kebijaksanaan itu ditentukan sendiri dengan mencatat dikeluarkan tanggal berapa dan kepada siapa saja telah diberikan. Kewajiban memberikan, memperlihatkan, atau memberitahukan isi Akta, Grosse Akta, Salinan Akta atau Kutipan Akta, ditentukan lain oleh peraturan perundang-undangan. Kewajiban yang ditentukan lain misalnya terhadap akta notaris wajib menyampaikan daftar wasiat kepada pusat daftar wasiat $^{37}$ dan memperlihatkan isi akta untuk uji petik dalam pemeriksaan oleh Majelis Pengawas Notaris $^{38}$ dan melaporkan pembuatan akta kepada Direktorat Jenderal Pajak ${ }^{39}$. Notaris juga wajib hadir memberikan keterangan di

\footnotetext{
${ }^{37}$ Lihat Pasal 16 ayat (11) huruf j UUJN ada sanksi bagi notaris yang tidak menyampaikan, baik administrasi maupun perdata Ibid., hlm. 262,

${ }^{38}$ Lihat Pasal Pasal 68-80 UUJN juncto Keputusan Menteri Hukum Dan Hak Asasi Manusia Republik Indonesia Nomor: M.39-PW.07.10 TAHUN 2004 tentang Pedoman Pelaksanaan Tugas Majelis Pengawas Notaris

${ }^{39}$ Lihat Pasal 25 ayat (1) Undang-undang nomor 20 tahun 2000 tentang Bea Perolehan Hak Atas Tanah dan Bangunan
} 
hadapan pengadilan jika hak ingkar atau telah diijinkan oleh Majelis Kehormatan Notaris. Terhadap pengecualian yang ditentukan oleh peraturan perundangundangan, notaris wajib menolak untuk memberikan salinan/grosse/kutipan akta. Terhadap orang-orang atau instasi yang memerlukan salinan/grosse/kutipan akta disampaikan sendiri oleh yang memperoleh. Instansi yang memerlukan salinan/grosse/atau kutipan akta dapat diberikan sebagai bagian dari dokumen pendukung/administrasi yang meminta sesuai dengan persyaratan tertulis atau tidak. Terhadap pengeluaran minuta akta umumnya notaris memilih mengeluarkan salinan. Salinan dipilih karena salinan merupakan salinan utuh dari sebuah minuta. ${ }^{40}$ Pengeluaran selain salinan untuk mencegah terjadi penolakkan yang diakibatkan tidak terkonstantirnya maksud dan kehendak instasi terkait sebagai

\footnotetext{
${ }^{40}$ Lihat Pasal 1 angka 9 UUJN
}

penerima dokumen. ${ }^{41}$ Diantara instansi yang mewajibkan adanya bantuan notaris, diantaranya berkaitan erat dengan jabatan notaris misalnya kementerian Hukum dan Hak Asasi Manusia ${ }^{42}$, kementrian Agraria dan Tata Ruang/Badan Pertanahan Nasional $^{43}$, kementrian Koperasi $^{44}$, Kementrian Agama ${ }^{45}$, dan Otoritas Jasa Keuangan $^{46}$.

Penyampaian terhadap salinan pada beberapa peraturan ditetapkan hanya dengan

\footnotetext{
${ }^{41}$ Liha penjelasan grosse dan kutipan dalam Pasal 1 angka 10 dan 11 UUJN

42 Notaris diangkat dan diberhentikan oleh Menteri Hukum dan Hak Asasi Manusia, Lihat Pasal 2 UUJN

43 Notaris yang menjabat juga sebagai pejabat pembuat akta tanah diangkat dan diberhentikan oleh Menteri Agraria Agraria dan Tata Ruang/Kepala Badan Pertanahan Nasional, lihat Pasal 5 ayat (1) Peraturan Pemerintah Republik Indonesia Nomor 37 Tahun 1998 tentang Peraturan Jabatan Pejabat Pembuat Akta Tanah

${ }^{44}$ Notaris yang ditetapkan sebagai pejabat pembuat Akta Koperasi yang diatur dalam Keputusan Menteri Negara Koperasi dan Usaha Kecil dan Menegah Republik Indonesia Nomor 98/Kep/M.KUKM/IX/2004 tentang Notaris Sebagai Pembuat Akta Koperasi

${ }^{45}$ Notaris yang ditetapkan sebagai Pejabat Pembuat Akta Ikraf Wakaf yang diatur dalam Pasal 27 Peraturan Menteri Agama Republik Indonesia Nomor 73 Tahun 2013 tentang Tata Cara Perwakafan Benda Tidak Bergerak dan Benda Bergerak Selain Uang 46 Notaris yang terdaftar sebagai profesi penunjang pasar modal wajib terlebih dahulu terdaftar di Otoritas Jasa Keuangan, lihat Pasal 2 Peraturan Otoritas Jasa Keuangan Nomor 67 /Pojk.04/2017 tentang Notaris yang Melakukan Kegiatan di Pasar Modal
} 
pemberian kuasa kepada notaris yang

menyampaikannya misalnya dalam $\mathrm{PT}^{47}$,

Perkumpulan $^{48}, \quad \mathrm{CV}^{49}$. Pilihan untuk

menyampaikan melalui misalnya fidusia ${ }^{50}$.

Kewajiban dari orang yang berkepentingan

langsung pada akta/ahli waris/orang yang

memperoleh hak yang tidak bisa dapat

dikuasakan misalnya dalam pendaftaran Hak

Tanggungan Elektronik, ${ }^{51}$ pencatatan

perjanjian nikah ${ }^{52}$, pencatatan akta sewa-

menyewa atau perjanjian pengikatan jual

beli dalam sertipikat ${ }^{53}$. Diluar itu merupakan

kebebasan dari orang yang berkepentingan

${ }^{47}$ Lihat Pasal 3 ayat (2) huruf a Peraturan Menteri Hukum Dan Hak Asasi Manusia Republik Indonesia Nomor 21 Tahun 2021 tentang Syarat dan Tata Cara Pendaftaran Pendirian, Perubahan, dan Pembubaran Badan Hukum Perseroan Terbatas,

${ }^{48}$ Pasal 3 Permenkumham 3/2016,

${ }^{49}$ Pasal 1 angka 6 Permenkumham 17/2018,

${ }^{50}$ Pasal 3 ayat (1) Peraturan Menteri Hukum dan Hak Asasi Manusia Republik Indonesia Nomor 25 Tahun 2021 tentang Tata Cara Pendaftaran, Perubahan, dan Penghapusan Jaminan Fidusia,

${ }^{51}$ Dalam pendaftaran pembebanan hak tanggungan, PPAT yang mengunggah dokumen-dokumen, salah satunya adalah pilihan untuk menggungah perjanjian pokok (kredit atau pembiayaan). Menggungah perjanjian pokok sangat disarankan karena hak tanggungan adalah perjanjian tambahan dari perjanjian pokok,

${ }^{52}$ Lihat lampiran Pencatatan perjanjian kawin poin 5a SE Kementrian Agama dan poin 6a SE Dukcapil, tertulis "pasangan suami dan/atau istri menyerahkan persyaratan",

${ }^{53}$ Pasal 127B Perkaban 16/2021, langsung pada akta/ahli waris/orang yang

memperoleh hak untuk menyampaikannya

salinan/grosse/kutipan akta seperti apa. ${ }^{54}$

Terhadap pemegang salinan/grosse/kutipan

akta untuk perbuatan tertentu

mempercayakan kepada notaris untuk

memberikan kepada pihak ketiga termasuk

rekan sesama notaris.

Terhadap kepercayaan notaris untuk

memberikan kepada pihak ketiga juga perlu

diperhatikan, walaupun hanya sekedar

menitipkan akta dan kemudian diambil oleh

pihak ketiga. Sanksi yang diberikan terhadap

\footnotetext{
54 Penyampain dokumen penduduk untuk beberapa perbuatan hukum akan melahirkan jaminan kebendaan (preferen) pada saat pendaftarannya misalnya fidusia, Hak Tanggungan, Hipotek

Ada kalanya juga penyampaian dokumen melahirkan keterikatan atas pihak ketiga contohnya perjanjian kawin Pendaftaran perjanjian kawin pada dasarnya terkait harta benda yang mengikat pihak ketiga, namun tidak dicatatkan memiliki dampak yang bertolak belakang dengan pembuatan perjanjian kawin karena tidak akan mengikat pihak ketiga sama sekali bagi para pihak berlaku asas pacta sund servanda, lihat putusan MA No. 585 K/Pdt.2012, untuk kepastian hukum misalnya penyampaian wasiat kepada pusat daftar wasiat, lihat Hery Kosman Sagala, "Analisis Yuridis Akibat Hukum Akta Wasiat yang Tidak Terdaftar Pada Pusat Daftar Wasiat Kementerian Hukum Dan Hak Asasi Manusia Republik Indonesia (Studi Putusan NO. 370/Pdt.G/2015/PN Mdn)", Tesis, Program Magister Kenotariatan Fakultas Hukum Universitas Sumatera Utara Medan, 2018, hlm 60-61.
} 
tidak menjaga kerahasiaan oleh notaris adalah: ${ }^{55}$

a. Pidana diatur dalam Pasal 322 Kitab

Undang-undang Hukum Pidana,

b. Perdata sebagai kategori melawan

hukum diatur dalam Pasal 1365

KUHPerdata,

c. Pidana penjara dan denda berdasarkan

Pasal 85 Undang-undang Nomor 43

Tahun 2009 tentang Kearsipan,

d. Administrasi sebagai sanksi jabatan diatur dalam Pasal 54 ayat (2) UUJN,

e. Kode etik karena tidak menjalankan jabatan sesuai dengan UUJN diatur dalam Kode Etik Ikatan Notaris Indonesia. $^{56}$

Sehingga untuk menghindari sanksi-sanksi ada baiknya notaris menyuruh membuat kuasa tertulis dari orang yang berkepentingan langsung pada akta/ahli

${ }^{55}$ Habib Adjie, Penafsiran Tematik Hukum Notaris Indonesia berdasarkan Undang-Undang Nomor 2 Tahun 2014 Tentang Perubahan atas UndangUndang Nomor 30 Tahun 2004 tentang Jabatan Notaris, PT Refika Aditama, Bandung, 2015, hlm 183-184,

${ }^{56}$ Lihat Pasal 82 ayat (1) UUJN "Notaris berhimpun dalam satu wadah Organisasi Notaris”, waris/orang yang memperoleh hak untuk menyampaikan salinan/grosse/kutipan akta jika itu memang hanya satu-satunya atau alternative atau menitipkan kepada notaris untuk menyampaikannya, kepada yang mengambil salinan/grosse/kutipan. Kuasa dapat diberikan dengan bentuk suatu akta umum, tulisan bawah tangan, surat yang hanya ditandangani oleh pemberi kuasa atau dengan kuasa lisan. ${ }^{57}$ Kuasa yang diberikan bijaksananya diterima secara tertulis mengingat pembuktian kuasa lisan sangat sulit. Kuasa tertulis juga dapat dilakukan dalam akta autentik biasa dilakukan pada PT, yayasan atau perkumpulan. ${ }^{58}$ Tanpa adanya kuasa itu jika notaris menyampaikan langsung maka dapat dikenakan sanksisanksi yang berlaku karena memberitahukan rahasia secara tidak berwenang.

\footnotetext{
${ }^{57}$ Lihat Pasal 1793 KUHPerdata,

${ }^{58}$ Namun perlu diperhatikan bahwa penggunaan kuasa yang belum tertulis namanya atau disebut kuasa blanko seperti pada akhir sebelum penutup akta PT atau yayasan, lihat Herlien Budiono, Op. cit., hlm 135
} 
Pada akhirnya kewajiban

merahasiakan merupakan kepentingan dari

notaris sendiri. Notaris yang tidak dapat

membatasi diri akan kehilangan kepercayaan

publik dan tidak lagi dianggap sebagai orang

kepercayaan (vertrouwenspersoon). ${ }^{59}$

Penutup

Kesimpulan

Notaris merupakan jabatan yang lahir karena

kebutuhan masyarakat yang dalam

perkembangannya dalam suatu peraturan

maupun kebijakkan yang bersifat tidak

tertulis dari masyarakat yang

mengkehendaki adanya campur tangan dari

notaris sebagai syarat mutlak, pilihan

kewenangan notaris, pejabat selain notaris.

Kewajiban untuk merahasiakan terhadap

kepercayaan yang merupakan kehendak

yang disampaikan oleh penghadap (-para)

lahir sendirinya karena jabatan notaris.

Sebagai kewajiban notaris untuk membuat

minuta dan menyimpannya sebagai protokol

maka notaris kepada orang yang

${ }^{59}$ GHS Lumban Tobing, Op. cit., hlm. 118, berkepentingan langsung pada akta, ahli waris, atau orang yang memperoleh hak diberikan salinan/grosse/kutipan akta. Notaris yang dihadapkan pada sulitnya menenentukan apakah seseorang bisa mendapatkan salinan/grosse/kutipan akta agar dapat meminta yang bersangkutan untuk meminta kuasa tertulis atau penetapan pengadilan untuk mengeluarkan dan memberikan salinan/grosse/kutipan akta pada pihak yang meminta kepada notaris. Sanksi yang diberikan terhadap tidak menjaga kerahasiaan oleh notaris adalah pidana, perdata, pidana penjara dan denda, administrasi, dan kode etik. Sehingga untuk menghindari sanksi-sanksi ada baiknya notaris menyuruh membuat kuasa tertulis dari orang yang berkepentingan langsung pada akta/ahli waris/orang yang memperoleh hak untuk menyampaikan salinan/grosse/kutipan akta.

\section{Saran}


Notaris tidak sewenang-wenang untuk menyampaikan salinan/grosse/kutipan akta kepada pihak ketiga tanpa adanya suatu kuasa walaupun instansi yang ditunju akrab dengan keseharian notaris

\section{Daftar Pustaka}

\section{Buku}

Adjie, Habib, Penafsiran Tematik Hukum Notaris Indonesia berdasarkan Undang-Undang Nomor 2 Tahun 2014 Tentang Perubahan atas UndangUndang Nomor 30 Tahun 2004 tentang Jabatan Notaris, PT Refika Aditama, Bandung, 2015.

Badan Pembinaan Hukum Nasional Kementerian Hukum Dan HAM RI 2013, Naskah Akademik Rancangan Undang Undang Hukum Kontrak, tanpa penerbit, tanpa tempat terbit, 2013

Budiono, Herlien, Demikian Akta Ini Tanya Jawab Mengenai Pembuatan Akta Notaris Di Dalam Praktik, Citra Aditya Bakti, 2018.

Kementerian Hukum Dan Hak Asasi Manusia RI Badan Pembinaan Hukum Nasional 2016, Naskah Akademik Rancangan UndangUndang Tentang Perkumpulan, tanpa penerbit, tanpa tempat terbit, 2016

Notodisuryo, Raden Soegondo, Hukum Notariat di Indonesia suatu penjelasan, RajaGrafindo Persada, Jakarta, 1993.

Peter Mahmud Marzuki, Penelitian Hukum, Preneda Media, Jakarta, 2005.

Tobing, GHS Lumban, Peraturan Jabatan Notaris, Erlangga, Jakarta, 1999.

\section{Hasil Penelitian/Tugas Akhir}

Hery Kosman Sagala, "Analisis Yuridis Akibat Hukum Akta Wasiat yang Tidak Terdaftar Pada Pusat Daftar Wasiat Kementerian Hukum Dan Hak Asasi Manusia Republik Indonesia (Studi Putusan NO. 370/Pdt.G/2015/PN Mdn)", Tesis, Program Magister Kenotariatan Fakultas Hukum Universitas Sumatera Utara Medan, 2018

\section{Artikel Jurnal}

Anisah Aprilia, "Alternatif Bentuk Wasiat Bagi Tenaga Kesehatan dan Pasien Covid-19”, Jurnal National Conference For Law Studies, Vol. 2, No. 1, 2020.

Asri Muji Astuti, "Honorarium Notaris Sebagai Upaya Untuk Melindungi Hak Notaris Guna Kepastian dan Keadilan", Jurnal Hukum UB, 2016.

Disemadi, H. S., Yusro, M.A., Shaleh, A.I (2020) Perlindungan Hukum Keputusan Bisnis Direksi BUMN Melalui Business Judgement Rule 
Doctrine, Jurnal Jurisprudence, Vol.10., No. 01. Pp. 127-145.

Endang Purwaningsih, "Bentuk Pelanggaran Hukum Notaris Di Wilayah Provinsi Banten dan Penegakan Hukumnya", Jurnal Mimbar Hukum, Vol. 27, No. 1, Februari 2015.

Innaka Dewi Hindra, Pieter Everhardus Latumeten, Widodo Suryandono, "Penerapan Asas Praduga Sah Terhadap Akta Notaris Dengan Adanya Figur Palsu (Studi Kasus Putusan Pengadilan Tinggi Banda Aceh Nomor 43/PDT/2017/PT.BNA)", Jurnal Indonesia Notary, Vol. 1, No. 004, tanpa bulan 2019.

Ivo Dewi Kumalawati, M. Khoidin, dan Nurul Ghufron, "Karakteristik Minuta Akta Notaris Sebagai Arsip Negara", Lex Humana Jurnal Hukum dan Humaniora, Vol. 1, No. 2, April-September 2017

Kristina Viri, Cornellius Bramantya, Josua Navirio Pardede, "Urgensi Rancangan Undang-Undang Perkumpulan", Jurnal Legislasi Indonesia, Vol. 18 No. 3, September 2021.

Paula Fransisca, Ro'fah Setyowati, "Wasiat Kepada Ahli Waris Menurut Kompilasi Hukum Islam dan Kitab UndangUndang Hukum Perdata",Jjurnal Notarius, Vol. 11, No. 1, 2018.

Siska Harun Buko, "Analisis Yuridis Tentang Kewajiban Notaris
Dalam Memberikan Jasanya Kepada Masyarakat yang Tidak Mampu Berdasarkan UU No. 2 Tahun 2014", Jurnal Lex Privatum, Vol. V, No. 1, JanFeb 2017

\section{Peraturan Perundang-Undangan}

Undang-undang Nomor 1 tahun 1974 tentang Perkawinan, Lembaran Negara Tahun 1974 Nomor 1, Tambahan Lembaran Negara Nomor 3019.

Undang-undang Nomor 4 Tahun 1996 tentang Hak Tanggungan Atas Tanah Beserta Benda-benda yang Berkaitan dengan Tanah, Lembaran Negara Tahun 1996 Nomor 42, Tambahan Lembaran Negara Nomor 3632.

Undang-Undang Nomor 42 Tahun 1999 tentang Jaminan Fidusia, Lembaran Negara Republik Indonesia Tahun 1999 Nomor 168, Tambahan Lembaran Negara Republik Indonesia Nomor 3889.

Undang-Undang Nomor 30 Tahun 2004 tentang Jabatan Notaris. Lembaran Negara Republik Indonesia Tahun 2014 Nomor 3 dan Tambahan Lembaran Negara Republik Indonesia Nomor 5491.

Undang-Undang Republik Indonesia Nomor 40 Tahun 2007 tentang Perseroan Terbatas. Lembaran Negara Republik Indonesia Tahun 2007 Nomor 106 dan Tambahan Lembaran Negara 


\begin{tabular}{|c|c|}
\hline $\begin{array}{l}\text { Republik } \\
4756 .\end{array}$ & Indonesia \\
\hline $\begin{array}{c}\text { ndang-Undang } \\
2009 \text { t } \\
\text { Lembaran } \\
\text { Indonesia } \\
152 \text { dan } \\
\text { Negara No }\end{array}$ & $\begin{array}{llr}\text { Nomor } & 43 \text { Tahun } \\
\text { tentang } & \text { Kearsipan. } \\
\text { Negara } & \text { Republik } \\
\text { Tahun 2009 Nomor } \\
\text { Tambahan Lembaran } \\
\text { mor 5071, }\end{array}$ \\
\hline $\begin{array}{l}\text { ndang-Undang } \\
2013 \\
\text { Kemasyara } \\
\text { Negara } \\
\text { Tahun 20 } \\
\text { Tambahan } \\
\text { Nomor } 543\end{array}$ & $\begin{array}{ll}\text { Nomor } & 17 \text { Tahun } \\
\text { tentang } & \text { Organisasi } \\
\text { akatan, } & \text { Lembaran } \\
\text { Republik } & \text { Indonesia } \\
13 \text { Nomor } & 2116 \text { dan } \\
\text { Lembaran Negara } \\
\text { 30. }\end{array}$ \\
\hline
\end{tabular}

Undang-Undang Republik Indonesia Nomor 2 Tahun 2014 tentang Perubahan Atas Undang-Undang Nomor 30 Tahun 2004 tentang Jabatan Notaris. Lembaran Negara Republik Indonesia Tahun 2014 Nomor 3 dan Tambahan Lembaran Negara Republik Indonesia Nomor 5491.

Undang-undang Nomor 11 tahun 2020 tentang Cipta Kerja, Lembaran Negara Republik Indonesia Tahun 2020 Nomor 245, Tambahan Lembaran Negara Republik Indonesia Nomor 6573

Peraturan Pemerintah Republik Indonesia Nomor 42 Tahun 2006 tentang Pelaksanaan Undang-Undang Nomor 41 Tahun 2004, Lembaran Negara Republik Indonesia Tahun 2006 Nomor 105, Tambahan Lembaran Negara Republik Indonesia Nomor 4668.
Peraturan Pemerintah Republik Indonesia Nomor 12 Tahun 2021 tentang Perubahan atas Peraturan Pemerintah Nomor 14 Tahun 2016 tentang Penyelenggaraan Perumahan dan Kawasan Permukiman Lembaran Negara Republik Indonesia Tahun 2021 Nomor 22, Tambahan Lembaran Negara Republik Indonesia Nomor 6624.

Instruksi Presiden Republik Indonesia Nomor 1 Tahun 1991 tentang Penyebarluasan Kompilasi Hukum Islam, Lembaran Lepas Sekretariat Negara Tahun 1991.

Peraturan Menteri Agama Republik Indonesia Nomor 73 Tahun 2013 tentang Tata Cara Perwakafan Benda Tidak Bergerak dan Benda Bergerak Selain Uang, Berita Negara Republik Indonesia Tahun 2013 Nomor 1047.

Peraturan Menteri Hukum dan Hak Asasi Manusia Republik Indonesia Nomor 3 Tahun 2016 tentang Tata Cara Pengajuan Permohonan Pengesahan Badan Hukum dan Persetujuan Perubahan Anggaran Dasar Perkumpulan, Berita Negara Republik Indonesia Tahun 2016 Nomor 115.

Peraturan Menteri Kesehatan Republik Indonesia Nomor 38 Tahun 2016 Tentang Penyelenggaraan Transplantasi Organ, Berita Negara Republik Indonesia Tahun 2016 Nomor 1273. 
Peraturan Otoritas Jasa Keuangan Nomor 42 /Pojk.03/2017 tentang Kewajiban Penyusunan dan Pelaksanaan Kebijakan Perkreditan atau Pembiayaan Bank bagi Bank Umum, Lembaran Negara Republik Indonesia Tahun 2017 Nomor 148 dan Tambahan Lembaran Negara Nomor 6091.

Peraturan Otoritas Jasa Keuangan Nomor 67 /Pojk.04/2017 tentang Notaris yang Melakukan Kegiatan di Pasar Modal, Lembaran Negara Republik Indonesia Tahun 2017 Nomor 288 dan Tambahan Lembaran Negara Nomor 6156.

Peraturan Menteri Hukum dan Hak Asasi Manusia Republik Indonesia Nomor 17 Tahun 2018 tentang Pendaftaran Persekutuan Komanditer, Persekutuan Firma, dan Persekutuan Perdata Berita Negara Republik Indonesia Tahun 2018 Nomor 1011.

Peraturan Menteri Negara Agraria/ Kepala Badan Pertanahan Nasional Nomor 16 Tahun 2021 tentang Perubahan Ketiga atas Peraturan Menteri Negara Agraria/Kepala Badan Pertanahan Nasional Nomor 3 Tahun 1997 tentang Ketentuan Pelaksanaan Peraturan Pemerintah Nomor 24 Tahun 1997 tentang Pendaftaran Tanah, Berita Negara Republik Indonesia Tahun 2021 Nomor 953.
Peraturan Menteri Hukum dan Hak Asasi Manusia Republik Indonesia Nomor 21 Tahun 2021 tentang Syarat dan Tata Cara Pendaftaran Pendirian, Perubahan, dan Pembubaran Badan Hukum Perseroan Terbatas, Berita Negara Republik Indonesia Nomor 470 Tahun 2021.

Peraturan Menteri Hukum dan Hak Asasi Manusia Republik Indonesia Nomor 25 Tahun 2021 tentang Tata Cara Pendaftaran, Perubahan, dan Penghapusan Jaminan Fidusia, Berita Negara Republik Indonesia Nomor 823 Tahun 2021.

Keputusan Menteri Hukum Dan Hak Asasi Manusia Republik Indonesia Nomor: M.39PW.07.10 TAHUN 2004 tentang Pedoman Pelaksanaan Tugas Majelis Pengawas Notaris.

Keputusan Menteri Negara Koperasi dan Usaha Kecil dan Menegah Republik Indonesia Nomor 98/Kep/M.KUKM/IX/2004 tentang Notaris Sebagai Pembuat Akta Koperasi.

Surat Edaran Mahkamah Agung 3 tahun 1963 tanggal 5 September

Surat Direktorat Jenderal Kependudukan dan Pencatatan Sipil Kementrian Dalam Negeri Republik Indonesia nomor 472.2/5876/Dukcapil.

Surat Direktorat Jenderal Bimbingan Masyakarat Islam Kementrian 
Agama Republik Indonesia

nomor

B.2674/DJ.III/KW.00/9/2017.

\section{Putusan Pengadilan}

Putusan Mahkamah Agung No. 585

K/Pdt.2012, mengenai

pembatalan perjanjian kawin

oleh Jacques Andre Germain

Ruc.

Putusan Mahkamah Konstitusi 69/PUU-XIII/2015 tentang

pengujian atas Undang-undang

Nomor 5 tahun 1960 tentang

Peraturan Dasar Pokok-Poko

Agraria dan Undang-undang

Nomor 1 tahun 1974 tentang

Perkawinan terhadap Undang-

Undang Dasar Negara Republik Indonesia Tahun 1945.

6. Lain-lain

Rapat Pleno Pengurus Pusat Yang Diperluas Ikatan Notaris Indonesia pada tanggal 12 Januari 2017 di Balikpapan. 